\title{
Art and legitimacy: from the discourse to the ideological rhetoric
}

Quote: SANTANNA, QUEIROZ, João Paulo. Art and legitmacy: from the discourse to the ideological rhetoric. Porto Arte: Revista de Artes Visuais. PPGAVUFRGS, v. 22, n. 36, p.1-7, jan.jun. 2017. e-ISSN 2179-8001. DOI: http://dx.doi. org/10.22456/2179-8001.80113

Translated by Ana Carolina Azevedo and Bruno Declerque

Abstract: The circuits of artistic legitimacy have been modified and replaced by new agents. On one hand, the "relational aesthetics" and the decentering observed in "altermodernism" (Nicolas Bourriaud). On the other, the modernist role of the academies and their respective inertia of reaction to the avant-gardes have for decades yielded their place to a "Bologna paradigm" of lifelong learning, along with the strengthening of discursive skills, both for students and for teachers (the puzzle articulation between degrees, masters and doctorates). In the field of publics, their inclusion as a relational media has created new platforms of interaction and social institution, based on informal and more interactive formulas: the associations, the collectives, the young curators. This whole movement can be framed in the so-called "educational turn", that is characterized by focusing on the public and its creation - or education - using safeguard institutions (museums, educational services, foundations) or schools and art institutes (the lifelong formation of professional artists, or the new agents (cities, artistic residences, interventions in local power).

Keywords: Educational turn. Alter Modern. Art and revolution. Curatorship.

\section{INTRODUCTION}

In a global panorama, it can be said that there is a tendency, or a collaborative emphasis, that crosses the artistic discourses of production and dissemination, also including the logics that reorganized the specialized artistic education and the curatorial discourses. With the emergence of new agents originated within the artistic process itself where the framing of interventions within a "relational aesthetic" has been gaining visibility, to which is added a decentering observed in the "AlterModern" (BOURRIAUD, 2009), which has been affirming a search for new centers, a call for new media and materials, and a general tendency in which the boundaries of the genre (i.e. "painting", "sculpture", "video art", etc.) have lost their categorizing importance in favor of a relational functionality that organizes the constitution of the works.
On the other hand, the academies saw their modernist role replaced, by the multiplication of educational levels (the Bologna process, which reformed higher education in Europe, the mobility programs, the lifelong learning, the curricula by credits with increasing vertical and horizontal mobility) made the anti-academic argument no longer applicable: the art student does not attend one academy, but three or more in his or her higher education, with multiple opportunities for mobility and curricular construction. At the same time, there is a growing demand for discursive skills, both from students and teachers (the introduction of academies in the universities created more logocentric and demanding professional careers, with multiple external evaluations, academic production requirements and numerous competitive examinations).

At the same time, the contemporary discourses, especially after the 60 's, have been using the repetition as an expressive resource, and the metalanguage as a process: the art is its own referent (GOMES, 2012), and the proposals establish with the public a game of messages, as if it was a private joke between artists, the wealth of reproduced and legitimated art, and the new public, knowledgeable of a pop expressiveness and a media culture that is increasingly dense (CORONA, 2016). Thus, the creative eclecticism is explored in divergent directions with affinity points, as in the rhizomes of the post-modern and iterative cross-referentiality (CATANI, 2007; SALVATORI, 2017; CUNHA, 2016).

Also, the inclusion of publics as a relational support to artistic interventions (from public art to social design, from collaborative expositions to the most implied educational services) has created interactive and institutional platforms that are more interactive: small associations and collectives have acquired preponderance, and recent artists have become, in an organic way, agents and curators. More and more the artist assimilates the tasks of a curator, managing exhibitions, interventions and performances, manifestations and collaborations.

The modernist topos of art criticism, once established as a gatekeeper, yields its influence to new entities inserted in the management and market logic: an event manager, a programmer that handles sponsors or that selects institutional acquisitions. The art critic is dislodged from the newspapers and the 
press, and tends to be replaced by "commissioners" with more stated interests in initiatives they promote.

Contemporary art takes on provisions where the reproduction of the economic circuit in a re-edition of the concepts of "resistance" and "incorporation" in a recodification of power begins to become more visible (HALL, 1980). In the midst of this update there is the cunning reproduction of power: the artists' incorporation tactics in the dominant discourses are made by collections, by museums, by the circuits of notoriety that have changed in the form and that conform the contents around a global tendency global.

\section{QUESTION: ART AND REVOLUTION}

When one mentions ideology, power, resistance and incorporation, one needs to mention conflicts, struggles of power, revolution, in terms of rhetorics, artistics. It is about permanently legitimizing power through new discourses, new forms, new agent.

But the implication in revolution and politics is a recent occupation of art. It hasn't been more than two or three centuries, which perhaps coincides with the 'new regime' of the French Republic - if we do not take into account the earliest immemorial political art. In fact, the period of the French Revolution summons some artists, in the effervescence of drawing the new dignity of the citizen in raising it to the heights of the academic frameworks. It affirms an organizing look of a more perfect society. As examples, the paintings and drawings by David, the "Serment du jeu de paume" ("Tennis Court Oath", from 1791), which could be a first instance of a document that states itself politically in order to change society. Also, the "Death of Marat," from 1793, elevates to the place of great art an incident more or less futile and with nothing heroic to it (the death of the publicist Marat at the hands of a disturbed woman while he was in the bath). It opens the way to a militant positioning, to plastic discourses that aim at an displaced, or even shocking, look (Goya, Delacroix, Courbet).

In a way, art finds a long program in the struggles of class, or to soften it, in the oppositions between Jacobins and Girondins, or, at the same time, liberals and absolutists. The planning and centralized regulation of the enlightenment taste was recent, as was the centrality of the arts around the ideal of academic elevation, by Le Brun and Poussin: the Academy was little more than a hundred years old (1648). It is true that the State had emerged in enlightened absolutism through centralized planning and the normalization of its general organization. Art becomes less religious, more civil, and converges to the State, as a representation of the absolute power of divine right: the gardens of Versailles, the paintings according to the hierarchies of the Academy, are now sponsored by the King. Art must be "clear and distinct" fulfilling the requirements of drawing, coloring, lighting, and composition. But above all, the thematic elevation, the grand goût, displaces the profane motives into the classical legitimacy of classical taste. Demanding iconographic standards are established and an imagined Olympian filled with what is representable and valuable in the King's galleries is constructed, which is compatible with the standards of the new enlightened despotism. From biblical or classical epics, painting reproduces what one imagines, trying to illustrate in a single carefully composed scene a complete and sequenced story. The narrative taste becomes more complex and demanding in respect to pathetic expressions, to anatomical torsions. The perfection of taste reproduces the perfection of the State, the discipline, a novelty, uses choreographies that are painted, or performed in court dances. The gestures mean, the smaller ones, extending to the minimum rules of the etiquette, like an eternal ceremonial protocol of the lever of Louis XIV (le petit lever, le grand lever). The arts agree in the same way, hierarchical, composed, organized, sophisticated and throw themselves into high rhetoric that elevates their Royal sponsor. The context is heroic.

\section{QUESTION: IS THE REVOLUTION APOLLONIAN}

So how does revolution come to the arts? Precisely because the arts present themselves in such a modeling and demanding way, so high and erudite, so differentiated and distant, so excellent in theme, design and color.

Academies are rhetorical rehearsal rooms for a vacant grandeur. They will be called upon to provide new reflections of dreamed programmatic perfection. The artists will claim the ApolIonian representation of the revolution, which desires a triumph of reason, perfect as the decorative arts, and as Versailles avenues. Sages, who want to reorganize society towards equality of citizenship, continue to search for the images and sounds of the 
new society, where there are oaths, flags, bravery, rescue of the oppressed, announcements of peace, and emperors who save.

After this "privatization" of art, which coincides with the opening of the Museum - republican agent of illustration of the now equal citizens - we have a gradual thematic change of taste and themes. The painting prefers a "Massacre at Chios" (Delacroix, 1824) that evokes the Greek War of Independence and refers to an episode that occurred in the previous year with "political" dimensions $(260 \times 325 \mathrm{~cm})$. Revolution comes to the painting, the implication summons intellectuals to the noblest quarrels, politics becomes Apollonian. The Salon provides the vehicle, the stage, where the following revolutions are prepared. The suffering of equals, the prayer of the humble, is also preferred to the portrait of noble environments. Realism will find Courbet, who claims of a current "realism", here and now, against the fable of the academy.

This is to reflect on art and society: why is art so central to revolution? Will it still be today?

\section{QUESTION: A CUBE THAT SLOWLY DIGESTS ITSELF}

Today there are several formulations of political intervention, by the collaborative matrix. Art summons real bodies and their vain consumer ornaments.

It intervenes through objects that we do not normally pay attention to: ice, salt, stones, clay, debris. It is the paradigm of appropriation, of resignification, of displacement, of metonymy. Interventions by artists challenge, through a symbolic economy, an alternative to the circuit of objects, which comes from the shift of values of things of consumption. The decontextualization and recontextualization takes place in the white chamber, in the modernist device. The "Cube" slowly assimilates its dissolving criticism (O'Doherty, 2002) through multiform installations. It is true that the processing is slow and majestic: great art cannot be assimilate too fast.

This is the appropriation of vestiges, industrial and commercial debris, ready-mades, raw materials, material and conceptual extensions of connective networks. Delayed: it recalls the pioneering intervention of cubist collages, the assemblages and installations from Duchamp, the juxtapositions from Fluxus, the appropriations from POP, the systematic connections from Art Povera, the conceptual Art and a more postconceptual contemporary, the net art, the glitch art, the video art, all of those enclose an attitude of displacement - acting on the paradigmatic, associative, metaphorical axis to use the structuralist terminology.

We spoke of the rhetorical positions that relate the materials and the senses. It seems to be simpler: it is played on objects contaminated by cultural investment. The Marxist infrastructure is based, in art, on the superstructure for a new relationship of production that seems to be where art likes to play (MARTINS \& ALMEIDA, 2013). The meanings of the objects are the signifiers of art, not to a rhetorical drift, but to a "rhetorical attack" that has been rampant in the last decades and which seems to be increasingly adopted as a strategy for the construction of meaning.

\section{QUESTION: REVOLUTION AND PARTICIPATION OF THE BODY}

In the big picture, things are called to the center (MEANA, 2001). Placed as new centers by systematic decentralization, the discourses are evidenced and established as plans of expression: the readings are metalinguistic and demand more and more participation from the spectator (PILLAR, 1999).

The result may be ambivalent: there is more meaning, more resistance, more adherence to critical thought, or its opposite, more meaning, more adherence to a dominant and uncritical incorporation. At this point, it seems risky to predict whether the drift is entirely driven by the reinforcement of a validation system, or whether it is generating real and new perspectives on the most difficult, the human.

To use art, to dress art, to extend art through the body, to inscribe bodies in art. This designation is very contemporary and at the same time can be a neo-romantic drift: the body is fragile, it is tisic, it is feverish, it is fetishized, it is dead, it is exposed as a relic of a desire for memory, it is the object of something orientalistic. We want a body that is in trance, non-existent, Pygmalion, digitized (NICOLAIEWSKY, 2012).

\section{QUESTION: RESISTANCE OR INCORPORATION}

The discourses of the body can be constructors of identities and testimonies of a disagreement between the signifiers and the contents that are increasingly binary, bit maps, that 
dispense the bodies. But the bodies are the ones who tell, who feel, who remember, who observe, who are located in the landscape.

The rhetoric needs moments of production and recognition, its "grammars" (VERÓN 1980, 1999) that are external to them, but conform to them.

The discourses of art are themselves rhetorics inserted in production grammars, subject to grammars of recognition, of which these articles are also part, along with the continued receipt of the work. It is true that one and the other grammar (of production and recognition) are both bearers of ideological imputation, of manifestation of power, of "cunning" of their reproduction (FOUCAULT, 1994), it is no less true that there is an asymmetry in these moments: the production is made up of structures of production, relations and knowledge frames that close in the defined time, while in recognition, the process remains open forever (HALL, 1980).

A surprise awaits us at the end of the revolution, the conservative reflux, which recalls the flavor of old concerns. Today's politics are very fast, full of pathos, of instantaneous and viral emotions. Campaigns are done with tweets. Epidermal emotions occupy the whole of a diseased, infertile, digitized landscape (QUEIROZ, 2016).

Thus, it seems more difficult a to a flat board, in the artistic intentionality, to cause uneasiness: can one be interventive without losing its innocence?

\section{QUESTION: IS THERE A FINANCIAL COLONIALISM}

The construction of a relational fabric may be spontaneous if we are at the colloquial level. At the level of the artistic agent, the interferences and the walls replicate the hegemonic devices of power, today associated with the financial world: money has its agenda, its preferential circuits, its coagulation zones in the form of artistic investment. This process usually dictates the exclusion of its first agents, the artists, or coerces them to an adhesion to hegemony.

If there is something that art includes in its definition, it is its vanity: men die, but their art remains, it is cared for, it deserves to be known, taught, shown, protected, spread.
They are contexts that are important to be understood, to be known, to convene. The spaces lacking discourses become anomic, colonized, with no identity, an instance of society without narrative (GARCÍA CANCLINI, 2010). The subject in question is ours, because we speak of identity, of cultural emancipation, of discursive autonomy. How is it possible for one to have identity, without recognition of communicative discourses? This is a problem that may help to understand the manifestations associated with subcultures, or with the movements towards the new populisms: beyond materiality and the increase of global consumption, there is no acknowledged communication of existing identities.

There is a generalized need, outside the centers of power, of truly emancipated discourses that are demanded (MARTÍN-BARBERO, 2003). Here we can find one of the places for a resistance positioning: to increase the discursive and emancipatory production, promoting the knowledge and the qualified recognition of artists and works, in a refocused positioning in the local and eccentric cultures, in the identities.

The situation of art is a threat and is increasingly dependent on contexts of participation (ARDENNE, 2006).

\section{QUESTION: ARE THERE NEW DISCOURSES FOR A DECOLONIZATION OF THE ARTIST}

The proposal is to build discourse, but reversing hierarchies. New discourses arise, in which the enunciators are the artists themselves, focusing on the work of other artists. Legitimate interests dissipate and fresh air enters the powerful art circuit. It is necessary to counteract resistance, by occupying space, constructing discourse, contributing with informed and qualified content.

The challenge is present: the production of these discourses, by artists, has a legitimacy calibrated by history, by diversity (NUNES, 2010). They will certainly have more or less justification, but their existence is not ignorable. The artist takes on more responsibility, incorporating agencies, not only on the side of solitary production, but also on the side of recognition, where the cycle of reproduction of power is completed (OLIVEIRA \& STRATICO, 2013). 
The eccentricities are sought in a process of new ideological decolonization. Elena Tejada, a Peruvian, is an example of this awareness of an identity miscegenation to protect and not to submerge:

In her performance, "Boundaries" [2000], Elena Tejada struggled to read art books in English - pronouncing the words as it's written - she climbed a table and, surrounded by books, ended up chewing and swallowing the pages of one of these incomprehensible repositories of the truth about art. (RADULESCU DE BARRIO, 2017)

Elena Tejada builds an emancipatory, demanding and interpellating persona, who exposes herself as fragile and takes on her power by confrontation. At the Lima Bienalle, in 1997, she urinated, with a bare waist, in front of the curators and critics present.

The model is formative, conscious, and ambitions for more: more relationship, more knowledge, more dissemination, more public, more discourses about art, more knowledge. It is a new aesthetic rather than relational (BOURRIAUD, 2009) it is a cognitive aesthetic.

The attitude is one of resistance. Overcoming the cognitive capitalism of the hegemonies of artistic discourse requires persistence and innovation. It is a challenge for everyone, artists, public, and formative agents: there is an educational movement in motion, a turning, that repositions collaborative practices and the creation of audiences at the center (ARNEEN, 2006; O'NEIL \& WILSON, 2010).

Recognition is built, attentive looks are given to artists who were neglected, the greater cognitive proximity is promoted, starting with an emancipation of artists and audiences (RANCIÈRE, 2010).

The project may be under its way: to make known who is yet to know, to operate eccentric relational circuits (BOURRIAUD, 2009; ARDENNE, 2006) and to give to collaboration a mutual knowledge that strengthens discourses, and gives rise to novelty in discourses about art.

\section{CONCLUSION: EDUCATIONAL TURN? COLLABORA- TIVE CUNNING?}

The artistic agent is a policy maker, and can be a generator of new audiences. Here is a justification for new forms of intervention in the field of artistic recognition, acting formatively, as it becomes more present and necessary (RIZZI, PIRAS \& MARANGOLO, 2010), through comprehensive artistic practices among all actors in the artistic sphere (TOURINHO, 2003). The context is known as "educational turn" (O'Neil \& WILSON, 2010) when it is observed a trend of convergence of agents towards collaborative, participatory, inclusive, on the part of institutions, schools, museums, dissemination and production platforms, artists and educators (friar, 1994). Agents are touched by an inclusive dynamic that benefits everyone. Artists find more ventilation and immediate notoriety, museums and art centers involve more people, widening their influence among audiences and showing to their sponsors, in a global neo-liberal context, more expressive visitor numbers. There is an economic bias in the process, which inscribes ideology in this educational turn. The implication may be apparent, education can be mere adherence, fun, entertainment. Art can become more fun and assemble experiences for all ages, not exactly for the best reasons, but rather because it feeds on more audience and has a bigger impact on a public that is now a consumer of the creative industries.

The anti-fine-arts tendency was affirmed with a full intentionality in the convening of relationships in the artistic conception. The artist has assumed a curatorial responsibility by including, as support, the social connections that activate the work. The proposed pieces do not lack communication channels, but are themselves the channels that make them exist. The paradigm is increasingly relational (BOURRIAUD, 2009) at the same time as the creation of audiences falls within the sphere of action of the author: the public already expects to be questioned, summoned, and seems to claim for larger portions of intervention.

At the same time, the multiplication of media - graffiti, the book, the community intervention platform - favors a rapprochement between the self-organized cooperative groups of artists and the capillary establishment of public networks, which, once created (or 'educated'), becomes itself a factor of demand.

This is a turbulent and appealing tendency that consolidates around the attentive eyes of the art world: there is a loss of univocity, the guardians of legitimation are discarded (BOURDIEU, 2001) the weight of gatekeeping is reduced (LEWIN, 1942; SHOEMAKER \& VOS, 2009). Here the 
territories widen, become coincident with the maps, with the drifts of the urban space, the city becomes a new media, the informal environments become opportunities for a greater educational intervention of the author (HUERTA, 2015). The fields of artistic intervention overlap with demographics, and the maps more closely match the territories. The artistic relation approaches a one-to-one proposal, the artist interpellates and is also called into question, in a almost molecular relation.

It is one of the multiform aspects of the "educational turn" in the arts (O'NEIL \& WILSON, 2010). The educational turn has multiple areas of intervention: when the artistic, curatorial, mediatic and institutional management discourse is oriented toward greater relational interaction, through the convening of new audiences, more visitors, more interaction by networks and mobile devices, more informal involvement through new spaces and new circuits of circulation, more formative involvement of artists in the production of discourses on art, more emphasis on artistic training through the most recurrent masters and doctorates, with new solutions of academic insertion, such as research based on practice , among many other instances (QUEIROZ, 2013).

The tectonic complexity of interacting forces favors the formation of new artistic formations, new expressions, being these more or less self-conscious, more or less disinterested forces, more or less dependent on the pressures of the economic circuit, more or less contaminated by a zeitgeist ideological (neoliberal), or, on the opposite, by an activist motivation sustained in the permanent themes of civil rights, ecology and sustainability, citizenship and education, inclusion and multiculturalism, and others that remain available. In this thematic reserve, and also in the networks of implication, one can conceal a "collaborative cunning" of a deeper, ideological character. This cunning can introduce an inverse effect, that of moving away from the educational side of contemporary trends - by the danger of providing a political alibi to shift art education out of formal education, reducing its workloads, or suppressing disciplines of the curriculum - because after all, museums and artists could take on this task. That would be one of the wiles of power.

\section{REFERENCES}

ARDENNE, Paul. Un arte contextual: creación artística en medio urbano, en situación, de intervención, de participación. Murcia: Cendeac. 2006. ISBN: 84-96299-40-6.

BOURDIEU, Pierre. "Sobre o poder simbólico". In: BOURDIEU, Pierre. O Poder Simbólico. Rio de Janeiro: Bertrand Brasil, p.07-16, 2001.

BOURRIAUD, Nicolas. (Ed.) AlterModern: at Tate Britain, Tate Triennial. London: Tate Modern, 2009. ISBN: 9781854378170. . Estética Relacional. São Paulo. Martins Fontes, 2009. ISBN 978-85-99102-97-8.

CATTANI, Icleia Borsa. Mestiçagens na arte contemporânea. Porto Alegre: Editora da UFRGS, 2007.

CORONA, Marilice. Território partilhado: cruzamento de linguagens, espaço de reflexão." PORTO ARTE. Porto Alegre: PPGAV/UFRGS, v. 21, n. 35, maio 2016, p.91-101.

CUNHA, Eduardo Figueiredo Vieira da. Fioravante and the emptiness: the drawing as strategy of absence. Estúdio, Lisboa, v. 7, n. 16, p.42-48, dez. 2016. Disponível em <http://www.scielo.mec.pt/scielo.php?script=sci arttext\&pid=S1647-61582016000400005Elng=ptEnrm= is $0>$. acessos em 11 set. 2017.

FOUCAULT, Michel. História da Sexualidade I: a vontade de saber. Lisboa: Relógio de Água, 1994. ISBN: 9789727082407

FRADE, Isabela Nascimento. $O$ barato da arte na praça: 0 artesanato na feira hippie de Ipanema. Dissertação de Mestrado. São Paulo: Escola de Comunicação e Artes, USP, 1994.

GARCÍA CANCLINI, Néstor. La sociedad sin relato: Antropología y estética de la inminencia. Buenos Aires, Madrid: Katz Editores. (2010) ISBN 978-987-1566-30-3.

GOMES, Paulo César Ribeiro. Pinturas encadernadas ou pinturas enquanto livros. Estúdio, Lisboa, v. 3, n. 6, p.115-123, dez. 2012 . Disponível em <http://www. scielo.mec.pt/scielo.php?script=sci_arttextEpid=S164761582012000200017\&lng=ptenrm=iso >. acessos em 11 set. 2017.

HALL, Stuart. Encoding / decoding. In In: HALL, D. HOBSON, A. LOWE, \& P. WILLIS (eds). Culture, Media, Language: Working Papers in Cultural Studies, 1972-79. p.128-138. 1980. Disponível em URL: http://www.hu.mtu.edu/ jdslack/ readings/CSReadings/Hall_Encoding-n-Decoding.pdf

HUERTA, R. Educación artística, derechos humanos y diversidad sexual. In HUERTA, R. y ALONSO-SANZ, A. (Eds.), Educación Artística y Diversidad Sexual (p.23-42). Valencia: 
Servicio de Publicaciones de la Universidad de Valencia, 2015. ISBN 978-84-370-9707-7.

LEWIN, Kurt. Forces behind food habits and methods of change. Bulletin of the National Research Council. 108:35-65. (1942)

MARTÍN-BARBERO, Jesús. Nuevas claves de la visibilidad social y la creatividad (seminario). Bogotá: Universidad Javeriana, Seminario de posgrado. 2003 [Consult. 2016-0224] Disponível em URL: http://pt.scribd.com/doc/19241339/ Seminario-Arte-comunicacion-y-tecnicidad

MARTINS, C. S., \& ALMEIDA, C. Que sentido para a investigação em educação artística senão como prática política?. Educação, Sociedade \& Culturas, (40) 2013.

MEANA, J. C.. El espacio entre las cosas, Arte y Estética. Diputacion de Pontevedra, 2001.

NICOLAIEWSKY, Alfredo. De Película: As narrativas fotográficas de Vera Chaves Barcellos. Estúdio, Lisboa, v. 3, n. 5, p.316-320, jun. 2012 . Disponível em <http://www. scielo.mec.pt/scielo.php?script=sci_arttextEpid=S1647$61582012000100053 \&$ Ing=ptEnrm=iso $>$. acessos em 10 set. 2017.

NUNES, Ana Luísa Ruschel. História da Arte e desenvolvimento do pensamento estético da criança: uma aprendizagem significativa. Revista Práxis Educativa, 5(1) 2010.

O'DOHERTY, Brian. No interior do cubo branco: a ideologia do Espaço da Arte. São Paulo: Martins Fontes. 2002. ISBN:8533616864

OLIVEIRA, Ronaldo Alexandre, \& STRATICO, Fernando A. Histórias do sujeito e formação em arte. DOI 10.5212/ PublicatioHuma.v.21i2.0005. Publicatio UEPG: Ciências Humanas, Linguistica, Letras e Artes, 21(2). 187-195. (2013)

O'NEIL, Paul \& WILSON, Mick (Ed.) Curating and the Educational Turn. London: Open Editions. 2010. ISBN 978-0-949004-18-5

PILLAR, Analice Dutra. Leitura e releitura. A educação do olhar no ensino das artes, 3, 9-22. (1999)

QUEIROZ, João Paulo. Discursos da Arte em Mudança. In CIRILLO, José \& GRANDO, Ângela (Ed.) O Sabor da sua Saliva é Sonoro: reflexões sobre o processo de criação nas artes. São Paulo: Intermeios Casa de Livros. p.148-157. 2013. ISBN: 978-85-64586-44-4 . Educação artística, casos e realidades: 'infirmitati,' ou a fraqueza analógica. In Novos Lugares para a Educação Artística: O V Congresso Matéria-Prima. Lisboa: Faculdade de Belas-Artes da Universidade de Lisboa \& Centro de
Investigação e Estudos em Belas-Artes. (2016) 735 p. ISBN: 978-989-8771-44-5. P.379-86. Disponível em http:// congressomateria.fba.ul.pt/actas_2016.pdf

RADULESCU DE BARRIO, Mihaela. Personajes y escenarios en las performances de Elena Tejada. Revista Estúdio, Artistas sobre outras obras. 8(20). 2017.

RANCIÈRE, Jacques. 0 espectador emancipado. Lisboa: Orfeu Negro. 2010. ISBN: 978-989-8327-06-2

RIZZI, C., PIRAS, F., \& MARANGOLO, P. Top-down projections to the primary visual areas necessary for object recognition: A case study. Vision research, 50(11), p.1074-1085. 2010.

SALVATORI, Maristela. 0 múltiplo em publicações de artistas: Röhnelt, Cattani e Mutran. Revista Estúdio, Lisboa, v. 7, n. 16, p.34-41, dez. 2016. Disponível em <http://www. scielo.mec.pt/scielo.php?script=sci_arttextEpid=S1647$61582016000400004 \varepsilon$ Ing=ptEnrm=iso > . acessos em 10 set. 2017.

SHOEMAKER, Pamela J.; VOS, Tim P. Gatekeeping Theory. New York: Routledge, 2009. ISBN 0415981395

TOURINHO, Irene. Transformações no ensino da Arte: algumas questões para uma reflexão conjunta. In BARBOSA, Ana Mae. Inquietações e mudanças no ensino da arte. $2^{\mathrm{a}} \mathrm{Ed}$. São Paulo: Cortez. 2003.

VERÓN, Eliseo. A produção do sentido. São Paulo: Cultrix, 1980. Esto no es un libro. Barcelona: Editorial Gedisa S.A. 1999.

João Paulo Queiroz: Professor at Universidade de Lisboa, Faculty of Fine Arts, Centre for research and studies in Fine Arts in Lisbon, Portugal.

(*) Text sent in 2017. 